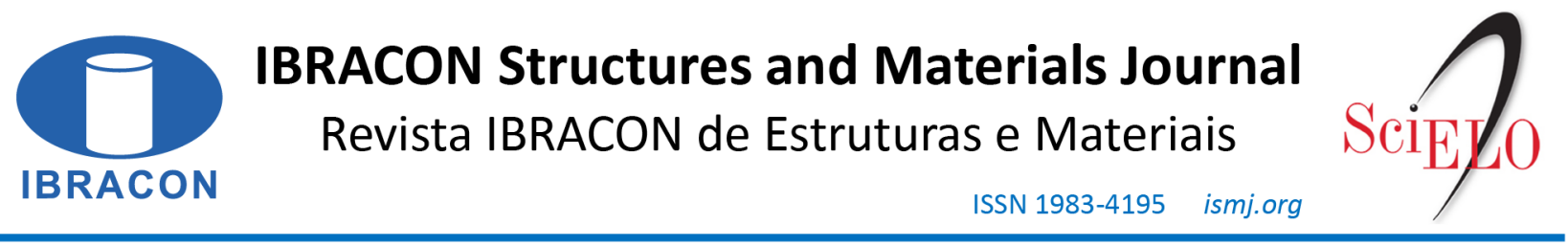

ORIGINAL ARTICLE

\title{
Corrosion evaluation of CA-50 steel in pore waters extracted from cement pastes with steel slags using electrochemical techniques
}

\author{
Avaliação da corrosão do aço CA-50 em meios de águas de poro extraídas de \\ pastas de cimento com escórias de aciaria usando técnicas eletroquímicas
}

\author{
Renan Esposito Vieira ${ }^{\mathrm{a}}$ (1) \\ Marina Martins Mennucci ${ }^{\mathrm{b}}$ (D) \\ Valdecir Angelo Quarcionic ${ }^{\mathrm{C}}$ (C) \\ Hercílio Gomes de Melo ${ }^{\mathrm{b}}$ (D)
}

\begin{abstract}
${ }^{a}$ Universidade de São Paulo (USP), Escola Politécnica, Departamento de Engenharia Química, São Paulo, SP, Brasil

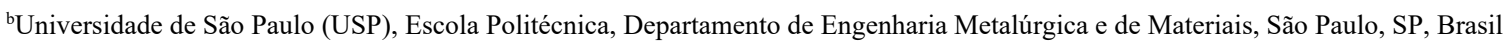

${ }^{\mathrm{c} I n s t i t u t o ~ d e ~ P e s q u i s a s ~ T e c n o l o ́ g i c a s ~ d o ~ E s t a d o ~ d e ~ S a ̃ o ~ P a u l o ~(I P T), ~ L a b o r a t o ́ r i o ~ d e ~ M a t e r i a i s ~ d e ~ C o n s t r u c ̧ a ̃ o ~ C i v i l, ~ S a ̃ o ~ P a u l o, ~ S P, ~ B r a s i l ~}$
\end{abstract}

Received 14 January 2020

Accepted 08 July 2020

\begin{abstract}
There is an interest in the cement industry in the use of steel slags in cement, but chemical and/or pyrometallurgical modifications are necessary to reduce the free $\mathrm{CaO}, \mathrm{MgO}$, and iron contents. However, the potential effects of its application in the reinforcement corrosion, whether in solid (concrete) or liquid medium (pore water), have not yet been addressed. In this context, the present study shows a corrosion analysis of the CA-50 steel in pore water medium extracted from cement pastes with $25 \%$ by weight of steel slag, in natural state or pyrometallurgical modified, by means of polarization curves, electrochemical impedance spectroscopy (EIS), and microstructural analysis. For comparison, tests were performed in pore waters presented in literature and representative from Ordinary Portland Cement (OPC) or activated Blast Furnace Slag (BFS) and, to simulate aggressive conditions, $1.0 \% \mathrm{NaCl}$ was also added to the solutions. The steel remained passive in all media without $1.0 \% \mathrm{NaCl}$, but the EIS results indicated more protective characteristics in the medium simulating the modified steel slag. The main corrosion product identified by SEM images after the tests on aggressive media was lepidocrocite $(\gamma-\mathrm{FeOOH})$, and the steel did not corrode in media with steel slags and $1.0 \% \mathrm{NaCl}$. This was attributed mainly to the higher alkalinity of these media in comparison to other usual pore waters, promoting longer protection of the steel.
\end{abstract}

Keywords: pore water, corrosion, steel slag, electrochemical impedance spectroscopy.

\begin{abstract}
Resumo: Existe interesse na indústria cimenteira no uso de escórias de aciaria em cimento, porém são necessárias modificações químicas e/ou pirometalúrgicas para redução dos seus teores de $\mathrm{CaO}$ e $\mathrm{MgO}$ livre e de ferro. Entretanto, ainda não se abordaram os potenciais efeitos de sua aplicação na corrosão de armaduras, seja em meios sólidos (concreto endurecido) ou líquidos (águas de poro). Nesse contexto, o presente estudo apresenta a análise da corrosão do aço CA50 em meios de águas de poro extraídas de pastas de cimento com $25 \%$ em massa de escória de aciaria (in natura ou modificada pirometalurgicamente) através de curvas de polarização, espectroscopia de impedância eletroquímica (EIE) e análises microestruturais. Para comparação, foram realizados ensaios em águas de poro de composições especificadas na literatura para cimento Portland comum e de escória de alto forno ativada com cimento, e posteriormente adicionouse $1,0 \% \mathrm{de} \mathrm{NaCl}$ às soluções para simular agressividade. $\mathrm{O}$ aço se manteve passivo em todos os meios sem $1,0 \% \mathrm{de}$ $\mathrm{NaCl}$, porém os resultados de EIE indicaram características mais protetoras no meio representativo de escória de aciaria modificada. O principal produto de corrosão identificado pelas micrografias do aço após os ensaios nos meios agressivos foi a lepidocrocita $(\gamma$-FeOOH), e não houve corrosão do aço nos meios com escórias de aciaria e 1,0\% de $\mathrm{NaCl}$. Isso foi atribuído principalmente à maior alcalinidade destes meios em comparação com outras águas de poro convencionais, $\mathrm{o}$ que promoveu proteção mais prolongada do aço.
\end{abstract}

Palavras-chave: água de poro, corrosão, escória de aciaria, espectroscopia de impedância eletroquímica.

Corresponding author: Renan Esposito Vieira. E-mail: revieira92@gmail.com.

Financial support: None.

Conflict of interest: Nothing to declare. 
How to cite: R. E. Vieira, M. M. Mennucci, V. A. Quarcioni, and H. G. Melo, "Corrosion evaluation of CA-50 steel in pore waters extracted from cement pastes with steel slags using electrochemical techniques," Rev. IBRACON Estrut. Mater., vol. 14, no. 2, e14209, 2021,

https://doi.org/10.1590/S1983-41952021000200009

\section{INTRODUCTION}

The use of additions in Portland cement brings benefits to the cement industry, as it allows a great reduction of $\mathrm{CO}_{2}$ emissions from the process and resources used in manufacturing. Among the most common addition is blast furnace slag, which is a byproduct of the manufacture of pig iron in the steel process and whose chemical composition of oxides is very similar to that of Portland cement (rich in $\mathrm{CaO}, \mathrm{SiO}_{2}$, and $\mathrm{Al}_{2} \mathrm{O}_{3}$ ), attributing good hydrological characteristics to the material [1]. As blast furnace slag, steel slag is a byproduct of the refining and steelmaking stage, and also has reactive oxides of Portland cement in its composition. However, the high contents of $\mathrm{CaO}$ and free $\mathrm{MgO}$, as well as the presence of inert phases (such as the "RO phase", which is a solid solution of $\mathrm{CaO}, \mathrm{MgO}, \mathrm{FeO}$, and $\mathrm{MnO}$ that promotes expansion in hardened cement) and considerable amounts of iron oxides, lead to the need for modifications by chemical or pyrometallurgical processes, as employed by authors in the literature [2]-[6], to allow the addition of higher contents in cement maintaining stability. The authors who used modified steel slag in their tests registered benefits, especially in mechanical terms, for the cement composite, which increases the interest in its application [2]-[6].

Generally, the literature focuses on studies of chemical, physical, and mechanical properties of cement composites with steel slag, not addressing the interactions and potential effects of this addition on the performance of concrete reinforcement. This analysis can be performed in solid media (involving tests with embedded reinforcement in mortar or concrete) or liquid media (tests on metals immersed in pore water). In the case of pore water media, Hooton et al. [7] pointed out that the extraction and analysis of this fluid from hardened cementitious materials has become, in recent times, a tool of great relevance and application in durability studies, once the correlation between the chemical composition of pore water and the solid phases of hardened material allows the prediction of phenomena that directly influence their behavior. For the specific case of reinforcement corrosion studies, pore water is easier to perform since it does not require the molding of specimens, and has, therefore, been used by several authors [8]-[15]. These tests are able to present coherent results in relatively short periods due to the good simulation of the alkalinity of the concrete interior.

Pore water is present in pores larger than $50 \AA$ in diameter of the hardened composite and is free from physical influences of the solid, not yet reacted and in direct contact with the reinforcement [16]. This fluid provides a great deal of information about the hydration of the material, the influence of the presence of additions and additives in the cement, aspects of alkaliaggregate reactions, alkali-silica, among many others [17]. Its extraction does not present any standardized procedure, and the best known and applied method in the literature is that of extraction by "application of triaxial pressure induced by force on the top of cylindrical specimens" [17]-[20]. The apparatus for this procedure is designed with defined parameters and materials, so that it supports several loads on the specimen. Such apparatus was initially presented by Barneyback and Diamond [18], and, in this study, the extractor used is similar to that of Oliveira [17], presented in Figure 1.

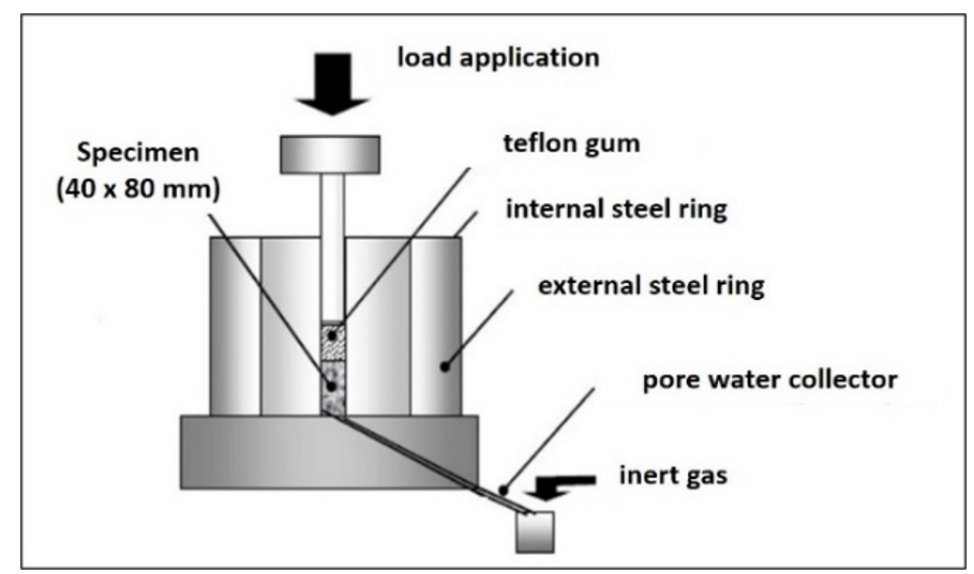

Figure 1. General scheme of the pressure pore water extractor used in this study. Source: Oliveira [17]. 
The pore water used in reinforcement corrosion studies is generally a mix of calcium, sodium, and potassium hydroxides in specific relations that result in high pH solutions. Authors such as Chen et al. [12], Koleva et al. [13], and Liu et al. [15] defended the feasibility of carrying out the studies in these liquid media, but indicating that their results are approximate for cement systems. In these studies, it is also common the use of electrochemical techniques such as the determination of Open Circuit Potential (OCP), polarization (linear or potentiodynamic), and electrochemical impedance spectroscopy (EIS). In the case of EIS, studies published by Sánchez et al. [10], Zhang et al. [11], and Liu et al. [15] presented relevant results and proved their efficacy for the analysis of passivation and corrosion of reinforcement immersed in pore waters. Sánchez et al. [10] studied the passivation mechanism for low carbon steel in pore water mainly through the results of EIS fitted by equivalent electrical circuits (EEC) and found important differences in the mechanisms related to different ages and spontaneous or potential induced growth of the passive layer. It was verified that there is a predominant diffusion control in the passivation for some ages and conditions, besides the surface charge transfer inherent to the system, which was evidenced by the obtained Nyquist diagrams from these tests. Zhang et al. [11] were able to discuss the differences between the influence of $\mathrm{pH}$ and chloride content variations in the medium for the passivation and corrosion of low carbon steel. The significant influence of the chloride content on the behavior of these steels was also confirmed by Liu et al. [15] in their study through EIS.

Considering the context, the present study investigated the passivation and corrosion of CA-50 steel in pore water media extracted by pressure from cement pastes with steel slag, in a natural state or modified by a pyrometallurgical process (for cement application), by means of electrochemical techniques (polarization curves and EIS) and microstructural analysis. In addition, tests were also performed in two pore waters extracted by Oliveira [17] from common Portland cement and activated blast furnace slag with cement pastes. The effect of chloride on the corrosion resistance of the material was evaluated by adding $1.0 \% \mathrm{NaCl}$ to pore waters with different compositions, and this percentage was selected considering that the Atlantic Ocean has a salinity of approximately 3.5\% [21]-[23] and the accelerated test literature varies the aggressiveness from $0.4 \%$ to $10 \%$ [8]-[13], [24].

\section{MATERIALS AND EXPERIMENTAL PROGRAM}

For the tests, specimens with $8 \mathrm{~mm}$ diameter and $10 \mathrm{~mm}$ long were cut from a CA-50 steel bar, and embedded in bakelite. The chemical composition of CA-50 steel determined by induction coupled plasma optical emission spectroscopy (ICP-OES) is shown in Table 1.

Table 1. Approximate composition of CA-50 steel.

\begin{tabular}{cccccc}
\hline Iron (Fe) & Carbon (C) & Manganese (Mn) & Phosphorus (P) & Silicon (Si) & Sulfur (S) \\
\hline $99.0 \%$ & $0.18 \%$ & $0.59 \%$ & $0.02 \%$ & $0.20 \%$ & $0.02 \%$ \\
\hline
\end{tabular}

Source: Results obtained by the Laboratório de Processos Metalúrgicos / IPT.

Initially, two synthetic pore waters were prepared according to the compositions determined by Oliveira [17] and which are representative of common Portland cement paste ("AP1", "Pore Water 1") and cement activated blast furnace slag paste ("AP2", "Pore Water 2"). For reference, consider Table 2 with the chemical compositions of these materials used by Oliveira [17].

Table 2. Chemical characterization of Portland Cement V - High Initial Resistance (CPV-ARI) and blast furnace slag used by Oliveira [17] (\% by mass).

\begin{tabular}{|c|c|c|c|c|c|c|c|c|c|c|c|c|}
\hline \multicolumn{13}{|c|}{ CPV-ARI cement (classic way) } \\
\hline $\mathrm{CaO}$ & $\mathrm{SiO}_{2}$ & $\mathrm{Al}_{2} \mathrm{O}_{3}$ & MgO & $\mathrm{Fe}_{2} \mathrm{O}_{3}$ & LI & IR & $\mathrm{CO}_{2}$ & $\mathrm{SO}_{3}$ & $\mathbf{S}^{2-}$ & $\mathrm{Na}_{2} \mathrm{O}$ & $\mathbf{K}_{2} \mathbf{O}$ & $\mathrm{CaO}_{\mathrm{f}}$ \\
\hline 65.6 & 19.2 & 4.98 & 0.36 & 3.17 & n.d. & n.d. & 1.76 & 2.96 & n.d. & 0.02 & 0.57 & n.d. \\
\hline \multicolumn{13}{|c|}{ CPV-ARI cement (flame photometry) } \\
\hline \multicolumn{13}{|c|}{$\mathrm{Na}^{+}$} \\
\hline \multicolumn{13}{|c|}{0.006} \\
\hline \multicolumn{13}{|c|}{ Blast furnace slag (classic way) } \\
\hline $\mathrm{CaO}$ & $\mathrm{SiO}_{2}$ & $\mathrm{Al}_{2} \mathrm{O}_{3}$ & $\mathrm{MgO}$ & $\mathrm{Fe}_{2} \mathrm{O}_{3}$ & LI & IR & $\mathrm{CO}_{2}$ & $\mathrm{SO}_{3}$ & $\mathrm{~S}^{2-}$ & $\mathrm{Na}_{2} \mathrm{O}$ & $\mathrm{K}_{2} \mathrm{O}$ & $\mathrm{CaO}_{\mathrm{f}}$ \\
\hline 42.47 & 33.78 & 13.11 & 7.46 & 0.51 & 1.67 & 0.53 & 1.18 & 0.15 & 1.14 & 0.16 & 0.32 & 0.1 \\
\hline \multicolumn{13}{|c|}{ Blast furnace slag (flame photometry) } \\
\hline & & & & & $\mathrm{Na}^{+}$ & $\mathrm{K}^{+}$ & & & & & & \\
\hline & & & & & 0.004 & 0.001 & & & & & & \\
\hline
\end{tabular}

n.d. - not determined. Source: Oliveira [17]. 
$1.0 \% \mathrm{NaCl}$ was added to the prepared pore water, resulting in " $\mathrm{AP} 1+1.0 \% \mathrm{NaCl}$ " and " $\mathrm{AP} 2+1.0 \% \mathrm{NaCl}$ " solutions, and, for reference, a $1.0 \% \mathrm{NaCl}$ solution was also used. After this step, pore water was obtained by pressure extraction of cement pastes with $25 \%$ by mass of steel slag, either in natura (EA) or modified by pyrometallurgical process (EAm). The characterizations of CP V-ARI cement and steel slag obtained by X-ray Fluorescence (XRF) and other wet method are presented in Table 3.

Once the mixtures (named "75CPV25EA" for the mix of CP V-ARI with 25\% EA and "75CPV25EAm" for the mix of CP V-ARI with $25 \%$ EAm) were prepared, cylindrical specimens with $40 \mathrm{~mm}$ diameter and $80 \mathrm{~mm}$ height were molded, according to geometric requirements of the extractor used in the study (Figure 1), with a water/cement ratio of 0.5 , which were cured for three days at a temperature of $(23 \pm 2){ }^{\circ} \mathrm{C}$ and relative humidity of $95 \%$. After this period, the specimens were demolded and taken for pore water extraction, which was performed by applying a load of 450 $\mathrm{MPa}$ at a rate of $2.5 \mathrm{MPa} \mathrm{s}^{-1}$.

Table 3. Chemical characterization of Portland cement and steel slag (\%).

\begin{tabular}{|c|c|c|c|c|c|c|c|c|c|c|c|c|c|c|c|}
\hline \multicolumn{16}{|c|}{ High Initial Resistance Portland Cement (CP V-ARI) } \\
\hline \multirow[t]{2}{*}{$\mathrm{CaO}$} & \multirow[t]{2}{*}{$\mathrm{SiO}_{2}$} & \multirow[t]{2}{*}{$\mathbf{A l}_{2} \mathbf{O}_{3}$} & \multirow{2}{*}{\multicolumn{2}{|c|}{ MgO }} & \multicolumn{2}{|c|}{$\mathrm{Fe}_{2} \mathrm{O}_{3}$} & \multirow{2}{*}{$\begin{array}{c}\text { Others } \\
\text { (1) }\end{array}$} & \multirow{2}{*}{$\begin{array}{c}\text { LI } \\
\text { (2) }\end{array}$} & \multirow{2}{*}{$\begin{array}{l}\text { IR } \\
\text { (2) }\end{array}$} & \multirow{2}{*}{$\begin{array}{c}\mathrm{CO}_{2} \\
\text { (2) }\end{array}$} & \multirow{2}{*}{$\begin{array}{c}\mathrm{SO}_{3} \\
(2)\end{array}$} & \multirow{2}{*}{$\begin{array}{l}\mathrm{S}^{2-} \\
\text { (2) }\end{array}$} & \multirow{2}{*}{$\begin{array}{c}\mathrm{Na}_{2} \mathrm{O} \\
\text { (2) }\end{array}$} & \multirow{2}{*}{$\begin{array}{c}\mathbf{K}_{2} \mathbf{O} \\
(2)\end{array}$} & \multirow{2}{*}{$\begin{array}{c}\mathrm{CaO} \\
\text { (2) }\end{array}$} \\
\hline & & & & & & & & & & & & & & & \\
\hline 63.3 & 19.3 & 4.81 & & 1.18 & & & 0.55 & 2.67 & 0.28 & 1.45 & 4.26 & nd & 0.49 & 0.95 & 1.85 \\
\hline \multicolumn{16}{|c|}{ In natura (EA) and pyrometallurgical modified (EAm) steel slag } \\
\hline \multirow[t]{2}{*}{$\%$} & $\mathrm{CaO}$ & $\mathrm{S}$ & $\mathrm{SiO}_{2}$ & & & & $\mathrm{MnO}$ & $\mathrm{P}_{2} \mathrm{O}_{5}$ & $\mathrm{Fe}_{2}$ & & & Others & $\mathrm{FeO}$ & $\mathrm{Fe}^{0}$ & $\mathrm{CaO}_{\mathrm{f}}$ \\
\hline & & & & & & & & & & & & (3) & (4) & (4) & (2) \\
\hline EA & 37.7 & 0.03 & 10.3 & & & & 4.12 & 1.15 & 11 & & 95 & 0.58 & 19.4 & 0.40 & 5.71 \\
\hline EAm & 34.3 & 0.05 & 30.7 & & & & 3.70 & 0.95 & 1. & & 38 & 0.46 & 7.50 & 0.40 & 0.21 \\
\hline
\end{tabular}

nd - not detected. (1) Others: $\mathrm{TiO}_{2}, \mathrm{Cr}_{2} \mathrm{O}_{3}, \mathrm{Mn}_{2} \mathrm{O}_{3}, \mathrm{SrO}, \mathrm{ZnO}, \mathrm{P}_{2} \mathrm{O}_{5}$. (2) Parameters are determined according to current technical standards of the classic Portland cement way. LI - Loss to Ignition; IR - Insoluble Residue; $\mathrm{CaO}_{\mathrm{f}}-$ Free $\mathrm{CaO}$. (3) Others: $\mathrm{TiO}_{2}, \mathrm{Cr}_{2} \mathrm{O}_{3}, \mathrm{SrO}$, ZnO. (4) Parameters are determined according to wet method procedures. $\mathrm{Fe}_{0}$ - metallic iron. Source: Results obtained by the Laboratório de Materiais de Construção Civil / IPT.

After extraction, the fluids were stored in hermetically sealed plastic flasks and taken immediately for determination of $\mathrm{pH}$ and volume extracted. Then, a volume $(0.5 \mathrm{~mL}$ or $1.0 \mathrm{~mL})$ was diluted to $10 \mathrm{~mL}$ and acidified with $\mathrm{HNO}_{3}$ for further determination of $\mathrm{Ca}^{2+}, \mathrm{Na}^{+}$, and $\mathrm{K}^{+}$ions (by atomic absorption spectroscopy, $\mathrm{AAS}$ ), $\mathrm{OH}^{-}$(by direct calculation from $\mathrm{pH}$ ) and $\mathrm{Cl}^{-}$(by ion chromatography). The pore water was characterized and extracted in duplicates and, with the results, synthetic compositions were prepared with $\mathrm{Ca}(\mathrm{OH})_{2}, \mathrm{NaOH}$, and $\mathrm{KOH}$. As for AP1 and AP2 solutions, $1.0 \%$ of $\mathrm{NaCl}$ was also added to the pore water to simulate aggressiveness.

Considering the procedure presented and the results obtained for the extracted pore water compositions, which will not be discussed in the present work, Table 4 summarizes the composition and $\mathrm{pH}$ of the pore water used for the electrochemical tests.

Table 4. Compositions and $\mathrm{pH}$ of the pore water of the study.

\begin{tabular}{|c|c|c|c|c|c|}
\hline Solutions / Reagents & $\mathrm{Ca}(\mathrm{OH})_{2}$ & $\mathrm{NaOH}$ & КОН & $\mathrm{NaCl}$ & pH \\
\hline Pore Water 1 (AP1) $^{(1)}$ & \multirow{2}{*}{ Sat. ${ }^{(2)}$} & \multirow{2}{*}{$0.004 \%$} & \multirow{2}{*}{$0.10 \%$} & - & 12.6 \\
\hline Pore Water $1+1.0 \% \mathrm{NaCl}(\mathrm{AP} 1+\mathrm{NaCl})$ & & & & $1.0 \%$ & 12.5 \\
\hline Pore Water 2 (AP2) ${ }^{(1)}$ & \multirow{2}{*}{ Sat. ${ }^{(2)}$} & \multirow{2}{*}{$0.20 \%$} & \multirow{2}{*}{$0.20 \%$} & - & 12.9 \\
\hline Pore Water $2+1.0 \% \mathrm{NaCl}(\mathrm{AP} 2+\mathrm{NaCl})$ & & & & $1.0 \%$ & 12.8 \\
\hline Pore Water "75CPV25EA" & \multirow{2}{*}{$0.02 \%$} & \multirow{2}{*}{$0.53 \%$} & \multirow{2}{*}{$1.27 \%$} & $0.01 \%$ & 14.0 \\
\hline Pore Water "75CPV25EA + 1.0\% NaCl" & & & & $1.0 \%$ & 13.9 \\
\hline Pore Water “75CPV25EAm" & \multirow{2}{*}{$0.01 \%$} & \multirow{2}{*}{$0.62 \%$} & \multirow{2}{*}{$1.45 \%$} & $0.01 \%$ & 14.0 \\
\hline Pore Water "75CPV25EAm $+1.0 \% \mathrm{NaCl}$ " & & & & $1.0 \%$ & 14.0 \\
\hline $1.0 \% \mathrm{NaCl}$ Solution & - & - & - & $1.0 \%$ & 7.20 \\
\hline
\end{tabular}

(1) Compositions obtained by Oliveira [17] and adopted for subsequent trials as references. (2) $\mathrm{Ca}(\mathrm{OH})_{2}$ solubility at $25^{\circ} \mathrm{C}^{\text {is }} 1.1 \mathrm{~g} \mathrm{~L}^{-1}[20]$.

The electrochemical tests were performed in a three-electrode cell with a platinum counter electrode, $\mathrm{Ag} / \mathrm{AgCl}$ reference electrode saturated with $\mathrm{KCl}$, and CA-50 steel embedded as a working electrode $\left(0.50 \mathrm{~cm}^{2}\right)$. For all tests, the working electrodes were sanded with \#320, \#400, \#600 and \#1200 grain silicon carbide sandpaper. 
- Potentiodynamic polarization: performed after one hour of OCP (Open Circuit Potential) stabilization. The cathodic and anodic curves were obtained with different electrodes, being the cathodic in the range of $+0.01 \mathrm{~V}$ to $-1.0 \mathrm{~V}$ and the anodic in the range of $-0.01 \mathrm{~V}$ to $+1.0 \mathrm{~V}$, both ranges relative to OCP, or until the current density reaches $\left|10^{-3}\right| \mathrm{A} \mathrm{cm}^{-2}$. The scan rate was $1.0 \mathrm{mV} \mathrm{s}^{-1}$.

- Electrochemical Impedance Spectroscopy (EIS): the evolution of the impedance behavior was followed with the immersion time of CA-50 steel in $1 \mathrm{~h}, 3 \mathrm{~h}, 6 \mathrm{~h}, 9 \mathrm{~h}, 12 \mathrm{~h}, 24 \mathrm{~h}, 48 \mathrm{~h}, 72 \mathrm{~h}$, and $120 \mathrm{~h}$ in the different pore waters without and with $1.0 \%$ chloride. The frequency range was $10^{4} \mathrm{~Hz}$ to $10^{-2} \mathrm{~Hz}$, at $\mathrm{OCP}$, with a perturbation amplitude of $10 \mathrm{mV}(\mathrm{rms})$ and eight measurements per decade of frequency. The $\mathrm{pH}$ of the solutions was also monitored over time.

- Scanning Electron Microscopy (SEM) and Energy Dispersion X-ray Spectroscopy (EDS): SEM micrographs were obtained from the specimens after anodic polarization tests on media containing $1.0 \% \mathrm{NaCl}$ in a FEI Quanta $450 \mathrm{FEG}$ equipment.

\section{RESULTS AND DISCUSSIONS}

Figure 2 shows the polarization curves obtained for CA-50 steel in pore water without (a) and with the addition of $1.0 \% \mathrm{NaCl}$ (b). For these media, the cathodic curves were very similar, presenting the control regions by oxygen diffusion (from $-0.7 \mathrm{~V} / \mathrm{Ag}-\mathrm{AgCl}$ and with $|\mathrm{i}|$ between $10^{-4}-10^{-5} \mathrm{~A} \mathrm{~cm}^{-2}$ ) and by hydrogen reduction (below -1.0 V/Ag-AgCl). According to Feng et al. [25] and Vago and Calvo [26], in alkaline media, the composition of the oxides formed on the surface of ferrous materials directly influences the evolution of the cathodic process, and it is suggested that such compositions, resulting from the reactions of oxygen, start to occur with greater intensity from $-0.7 \mathrm{~V} / \mathrm{Ag}-\mathrm{AgCl}$, which explains the behaviors verified in Figures $2 \mathrm{a}$ and $2 \mathrm{~b}$, in which the curves are dependent on the potential up to this value.

Unlike the cathodic branch, the anodic behaviors presented particular points. To assess the discussion, consider Table 5, which presents the electrochemical parameters obtained from the polarization curves of Figure 2. For the chloride-free media, Figure 2a, there is a little difference between the behaviors in the different solutions of pore water, and the curves for the media "AP1" and "AP2" showed slightly more polarized near the corrosion potential. However, the passive current densities for CA-50 steel were similar in all media, being slightly higher for "75CPV25EAm" pore water. Around $+0.6 \mathrm{~V} / \mathrm{Ag}-\mathrm{AgCl}$ (Table 5), the sudden increase in current density observed for the experiments presented in Figure 2a is attributed to the evolution of oxygen [8], [12], [13], confirmed by the formation of bubbles on the surface of the working electrodes. Finally, it is highlighted that the integrity of the specimens was maintained, showing passive behavior in the pore water in the absence of chlorides.

In the case of Figure $2 \mathrm{~b}$, the addition of $1.0 \% \mathrm{NaCl}$ had a significant influence on anodic behaviors, allowing to differentiate the corrosion resistance of CA-50 steel in the studied pore water solutions. In the "AP1" and "AP2" media (compositions in Table 4) [17], the anodic curves are characterized by a small passive region that extends up to approximately $0 \mathrm{~V}(\mathrm{Ag} / \mathrm{AgCl})$, followed by a sudden increase in the current, characterizing the oxide layer breakdown and the beginning of localized corrosion.

The pitting and corrosion potentials and the corrosion current densities of these media are close and in the same order of magnitude (Table 5), indicating the proximity of steel performance, although the anodic curve in medium "AP1 $+1.0 \% \mathrm{NaCl}$ " has shown to be more depolarized than in medium "AP2 $+1.0 \% \mathrm{NaCl}$ ", indicating greater susceptibility to corrosion.

Still referring to the results presented in Figure $2 b$, when it comes to the steel slag with $1.0 \% \mathrm{NaCl}$ media, a different anodic evolution between the two solutions can be observed. For the medium involving in natural slag, the anodic curve is more depolarized than in the modified slag medium, not allowing the precise definition of a passive current density, which indicates greater instability of the passive oxide layer in this medium. However, even considering this response, the steel remained passive until the evolution of oxygen in approximately $+0.6 \mathrm{~V} / \mathrm{Ag}-\mathrm{AgCl}$ (Table 5). On the other hand, in the $75 \mathrm{CPV} 25 \mathrm{EAm}+1.0 \% \mathrm{NaCl}$ pore water, the anodic polarization curve was quite similar to that obtained in the medium without chloride, indicating greater stability of the passive layer in this medium. Note that for the $75 \mathrm{CPV} 25 \mathrm{EAm}+1.0 \% \mathrm{NaCl}$ anodic curve the increasing current density is also attributed to oxygen evolution.

Comparing the results of the anodic curves obtained in the pore water of common cement pastes (AP1 $1.0 \% \mathrm{NaCl}$ and $\mathrm{AP} 2+1.0 \% \mathrm{NaCl}$ ) with those obtained in the pore water of slag cement pastes ("75CPV25EA $+1.0 \% \mathrm{NaCl}$ " and "75CPV25EAm $+1.0 \% \mathrm{NaCl}$ "), relevant differences are verified. As explained in the previous paragraph, the addition of $1.0 \% \mathrm{NaCl}$ was not sufficient to promote localized corrosion of the steel in these two latter media, indicating that this content is still below the limit chloride concentration [12], [15]. This behavior may be directly related to the higher alkalinity of these pore water solutions (Table 4), helping to maintain the integrity of the passive film. 


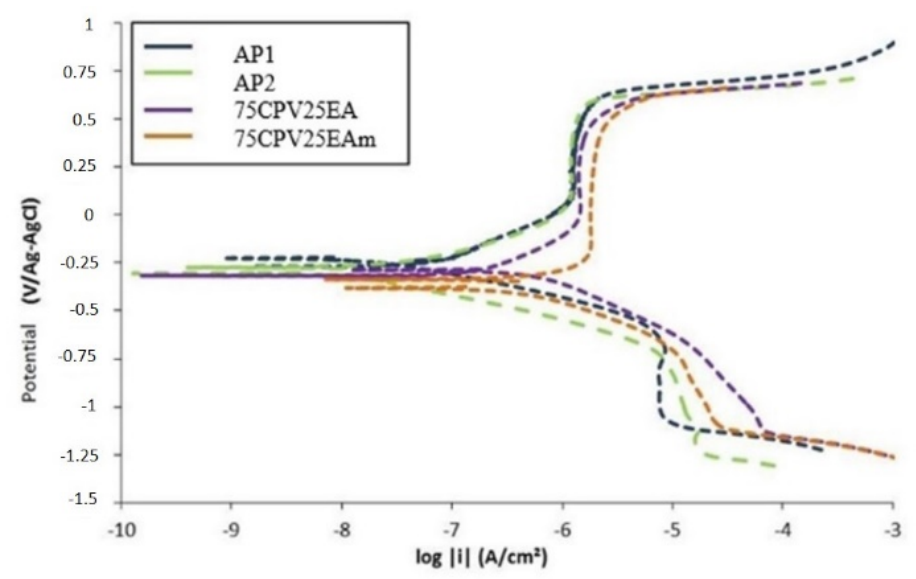

(a)

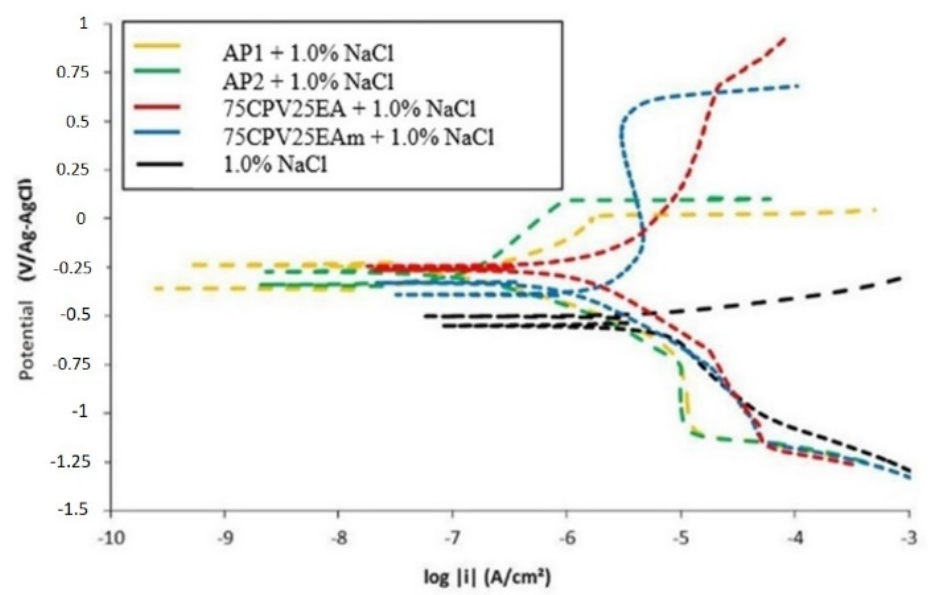

(b)

Figure 2. Polarization curves for CA-50 steel in pore water without (a) and with the addition of $1.0 \% \mathrm{NaCl}$ (b). Each branch of the curves was obtained with a different electrode.

Table 5. Electrochemical parameters determined from the triplicate of the CA-50 steel polarization curves in the different pore water simulant solutions.

\begin{tabular}{|c|c|c|c|c|c|}
\hline Solutions & $\begin{array}{c}\text { ipassive }(\mu \mathrm{A} \\
\left.\mathbf{c m}^{-2}\right)\end{array}$ & $\begin{array}{l}\mathbf{i}_{\text {corr }}^{(1)}(\mu \mathrm{A} \\
\left.\mathbf{c m}^{-2}\right)\end{array}$ & $\mathrm{E}_{\text {corr }}(\mathrm{V} / \mathrm{Ag}-\mathbf{A g C l})$ & $\begin{array}{c}\text { EO2/OH- (V/Ag- } \\
\text { AgCI) }\end{array}$ & $\begin{array}{c}\mathrm{E}_{\text {pitting }}(\mathrm{V} / \mathrm{Ag}- \\
\mathrm{AgCl})\end{array}$ \\
\hline Pore Water 1 (AP1) & $1.32 \pm 0.25$ & 0.79 & $(-0.27 \pm 0.04)$ & $(+0.67 \pm 0.01)$ & - \\
\hline $\begin{array}{c}\text { Pore Water } 1+1,0 \% \mathrm{NaCl}(\mathrm{AP} 1+ \\
\mathrm{NaCl})\end{array}$ & - & 0.65 & $(-0.36 \pm 0.01)$ & - & $(-0.008 \pm 0.02)$ \\
\hline Pore Water 2 (AP2) & $1.38 \pm 0.17$ & 0.71 & $(-0.27 \pm 0.01)$ & $(+0.59 \pm 0.02)$ & - \\
\hline $\begin{array}{c}\text { Pore Water } 2+1,0 \% \mathrm{NaCl}(\mathrm{AP} 2+ \\
\mathrm{NaCl})\end{array}$ & - & 0.71 & $(-0.33 \pm 0.04)$ & - & $(+0.05 \pm 0.04)$ \\
\hline Pore Water "75CPV25EA" & $1.38 \pm 0.13$ & 0.38 & $(-0.31 \pm 0.04)$ & $(+0.57 \pm 0.05)$ & - \\
\hline $\begin{array}{c}\text { Pore Water "75CPV25EA + 1,0\% } \\
\text { NaCl" }\end{array}$ & - & 2.69 & $(-0.34 \pm 0.06)$ & $(+0.53 \pm 0.01)$ & - \\
\hline Pore Water "75CPV25EAm" & $1.70 \pm 0.13$ & 0.38 & $(-0.31 \pm 0.05)$ & $(+0.62 \pm 0.04)$ & - \\
\hline $\begin{array}{l}\text { Pore Water "75CPV25EAm }+1,0 \% \\
\text { NaCl" }\end{array}$ & $3.07 \pm 0.91$ & 4.68 & $(-0.40 \pm 0.02)$ & $(+0.64 \pm 0.03)$ & - \\
\hline $1,0 \% \mathrm{NaCl}$ Solution & - & 10.0 & $(-0.51 \pm 0.01)$ & - & - \\
\hline
\end{tabular}

(1) $i_{\text {corr }}$ was determined from the analysis of the curves in Figures $2 a$ and $2 b$

Figures 3 and 4 show the evolution of EIS test results with time for pore waters without (Figure 3) and with 1.0\% $\mathrm{NaCl}$ (Figure 4). 

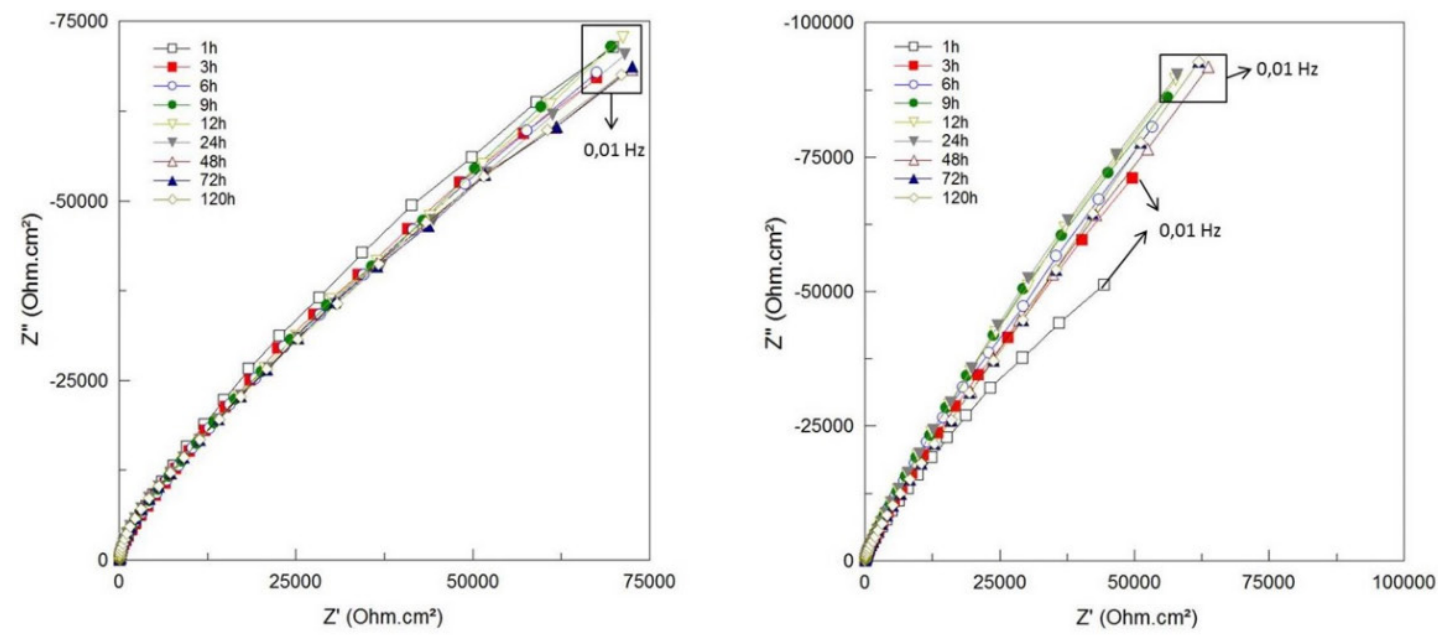

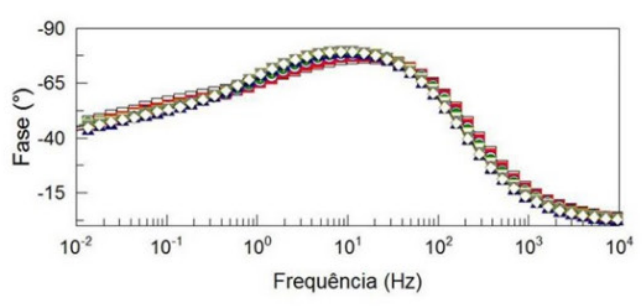

(a)
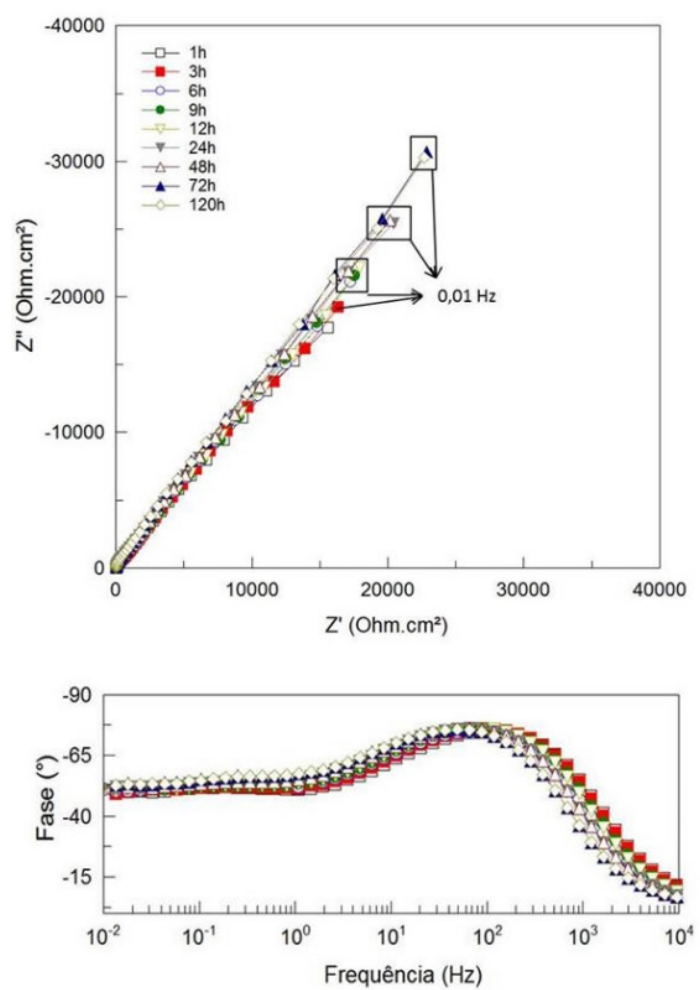

(c)

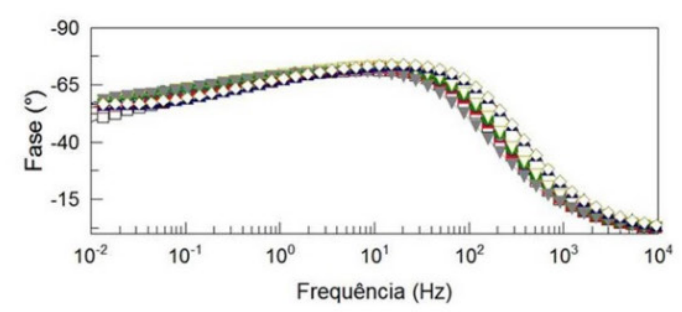

(b)
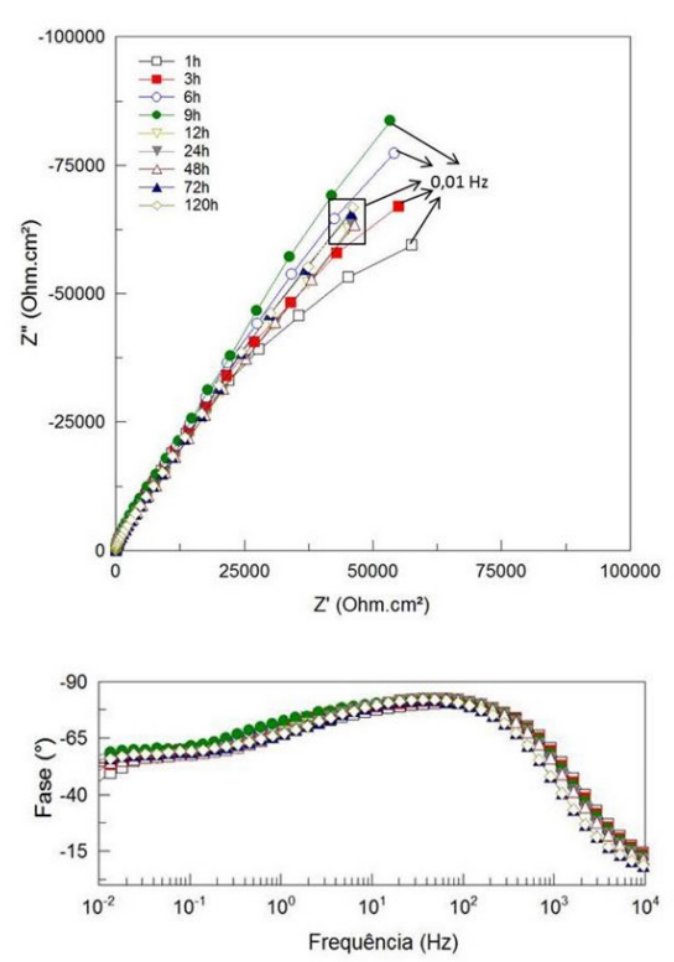

(d)

Figure 3. Nyquist and phase angle diagrams ( $\varphi$ versus $\log$ f) with immersion time for CA-50 steel in pore water: (a) AP1 (common Portland cement [17]). (b) AP2 (blast furnace slag [17]). (c) 75CPV25EA (75\% CP V-ARI + 25\% natural steel slag). (d) 75CPV25EAm (75\% CP V-ARI + 25\% modified steel slag). Diagrams obtained at the OCP. 


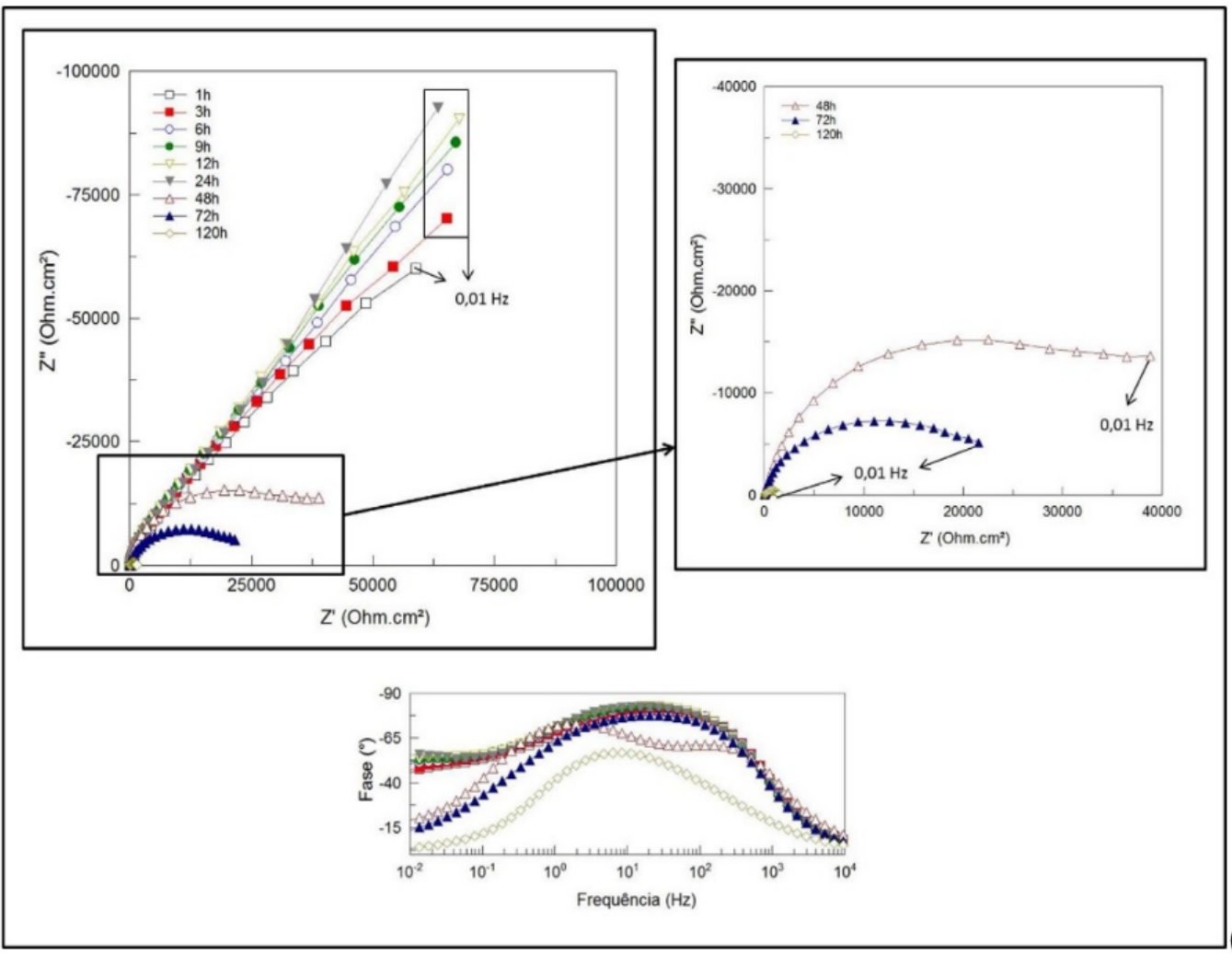

(a)

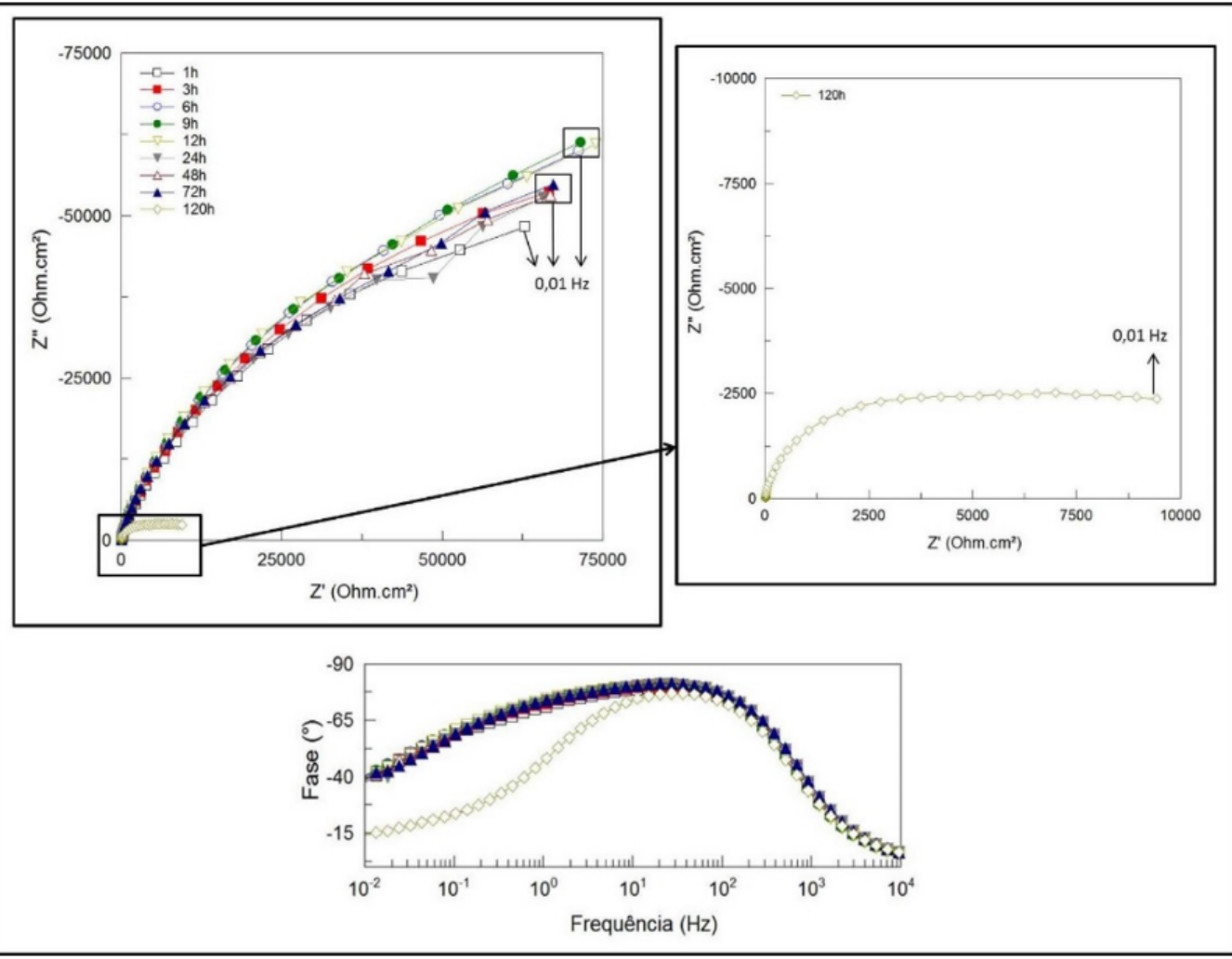

(b)

Figure 4. Nyquist and phase angle diagrams ( $\varphi$ versus $\log \mathrm{f}$ ) with immersion time for CA-50 steel in pore water: (a) AP1 $+1.0 \%$ $\mathrm{NaCl}$ (common Portland cement [17]). (b) $\mathrm{AP} 2+1.0 \% \mathrm{NaCl}$ (blast furnace slag [17]). (c) $75 \mathrm{CPV} 25 \mathrm{EA}+1.0 \% \mathrm{NaCl}$ (steel slag in natura). (d) $75 \mathrm{CPV} 25 \mathrm{EAm}+1.0 \% \mathrm{NaCl}$ (modified steel slag). Diagrams obtained at the OCP. 


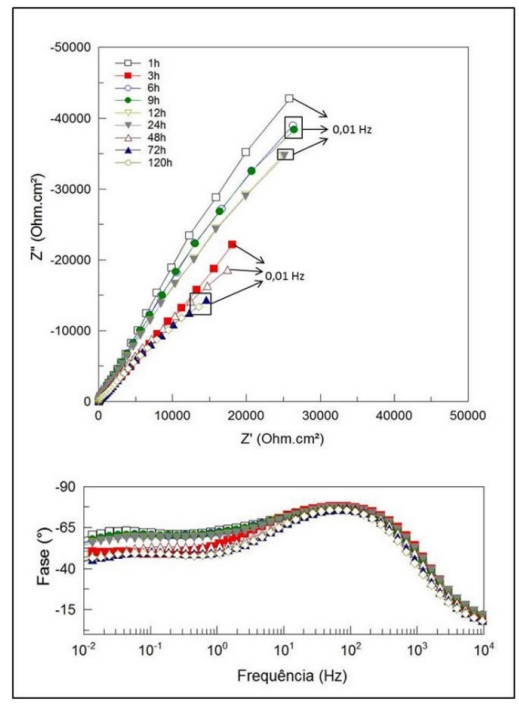

(c)

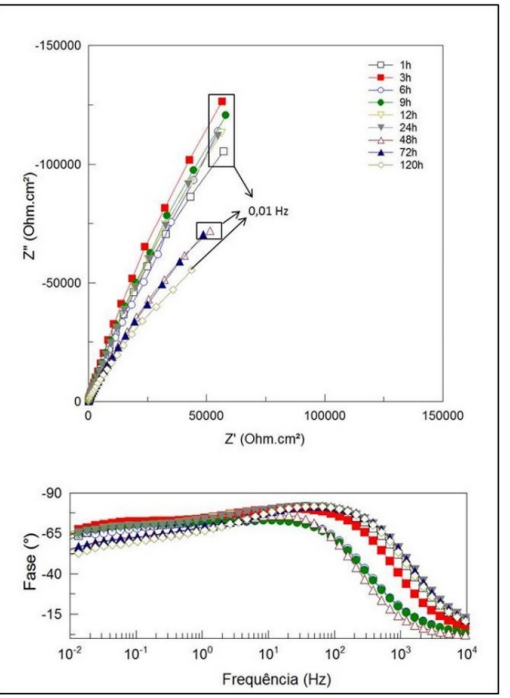

(d)

(Continuation) Figure 4. Nyquist and phase angle diagrams ( $\varphi$ versus log $f$ ) with immersion time for CA-50 steel in pore water: (a) AP1 $+1.0 \% \mathrm{NaCl}$ (common Portland cement [17]). (b) AP2 + 1.0\% NaCl (blast furnace slag [17]). (c) 75CPV25EA

$+1.0 \% \mathrm{NaCl}$ (steel slag in natura). (d) $75 \mathrm{CPV} 25 \mathrm{EAm}+1.0 \% \mathrm{NaCl}$ (modified steel slag). Diagrams obtained at the OCP.

In the absence of chlorides (Figure 3), the phase angle diagrams showed the presence of two-time constants in all media, being one strongly capacitive at high frequencies (HF), with phase angles above $70^{\circ}$. In the region of low frequencies (BF), there was a decrease in the phase angle, and its variation with frequency presents a linear trend, which indicates the existence of diffusion-controlled processes, a fact confirmed by the Nyquist diagrams. For all media, the evolution of the Nyquist diagrams indicated the stability of the impedance module with the immersion time and, in the first hours, the most intense variations are related to the evolution of the passive film and the stabilization of the potential of steel in the media. The $\mathrm{pH}$ monitoring for these media, as well as for those containing $1.0 \% \mathrm{NaCl}$, is presented in Table 6. For pore waters AP1 and AP2 (Table 4) [17], there was a small drop in $\mathrm{pH}$ in $72 \mathrm{~h}$, while for pore waters representative of steel slag the $\mathrm{pH}$ remained very alkaline up to $120 \mathrm{~h}$.

Table 6. $\mathrm{pH}$ monitoring of pore water during impedance tests.

\begin{tabular}{|c|c|c|c|c|c|}
\hline Solutions & Initial & $24 \mathrm{~h}$ & $48 \mathrm{~h}$ & $72 \mathrm{~h}$ & $120 \mathrm{~h}$ \\
\hline Pore water 1 (AP1) & 13.3 & 13.2 & 13.1 & 11.1 & 11.0 \\
\hline Pore water $1+1.0 \% \mathrm{NaCl}(\mathrm{AP} 1+\mathrm{NaCl})$ & 13.2 & 13.1 & 12.9 & 11.5 & 11.1 \\
\hline Pore water 2 (AP2) & 13.2 & 13.1 & 12.5 & 11.0 & 10.9 \\
\hline Pore water $2+1.0 \% \mathrm{NaCl}(\mathrm{AP} 2+\mathrm{NaCl})$ & 13.1 & 13.1 & 12.4 & 11.5 & 10.8 \\
\hline Pore water "75CPV25EA" & 14.0 & 14.0 & 13.9 & 13.8 & 13.7 \\
\hline Pore water "75CPV25EA $+1.0 \% \mathrm{NaCl}$ " & 14.0 & 14.0 & 13.8 & 13.9 & 13.8 \\
\hline Pore water "75CPV25EAm" & 14.0 & 13.9 & 13.9 & 13.9 & 13.7 \\
\hline Pore water "75CPV25EAm $+1.0 \% \mathrm{NaCl}$ " & 14.0 & 14.0 & 13.9 & 13.9 & 13.9 \\
\hline
\end{tabular}

For pore water containing $1.0 \% \mathrm{NaCl}$, diagrams presented in Figure 4, there was a difference in the impedance behavior of CA-50 steel between the solutions of Portland cement (AP) and slag cement. For the tests in "AP1 $+1.0 \% \mathrm{NaCl}$ " and "AP2 $+1.0 \% \mathrm{NaCl}$ ", the Nyquist diagrams showed a capacitive and stable behavior during the first hours of testing, but since $48 \mathrm{~h}$ for the first solution and $72 \mathrm{~h}$ for the second, there was a strong drop in the impedance of the steel and changes in the shapes of the Bode diagrams, indicating the beginning of localized attack, which was confirmed by visual analysis of the specimens after the tests. On the other hand, in the pore waters of steel slag, the specimens maintained relatively stable behavior up to $120 \mathrm{~h}$, which is evident through the high values of the impedance module. However, during the test, the impedance modules showed variations over time, which alternated between increases and decreases and may be associated with the action of chloride ions, promoting instability in the passive film.

The information displayed in Table 6 is very relevant to explain the observed behaviors. In the case of the media used by Oliveira [17], which are AP1 and AP2 (compositions in Table 4), with and without 1.0\% of $\mathrm{NaCl}$, there was a drop in pH 
throughout the test, and the process was intensified in 72 hours. At the end of the test $(120 \mathrm{~h})$, the $\mathrm{pH}$ of the pore water was around 11 for all solutions. This $\mathrm{pH}$ value is not sufficient to promote carbonation, which tends to occur at $\mathrm{pHs}$ below 10 [27], [28]. Thus, the destabilization of the passive layer is due to the presence of chloride ions, causing localized corrosion. On the other hand, the pore water related to the steel slag kept the steel passive up to $120 \mathrm{~h}$ even in aggressive media (with the addition of $1.0 \% \mathrm{NaCl}$ ). The high $\mathrm{pH}$, which was kept practically unchanged throughout the test, promoted more intense protection of the steel, and the addition of $1.0 \% \mathrm{NaCl}$ did not allow reaching the limit chloride concentration for the occurrence of localized attack of the passive layer at this $\mathrm{pH}$ value.

Figure 5 presents selected micrographs of the SEM analysis of the corroded regions of CA-50 steel in the media "AP1 $+1.0 \% \mathrm{NaCl}$ " and "AP2 $+1.0 \% \mathrm{NaCl}$ " after the anodic polarization tests. It is verified, in both media, the formation of a corrosion product with morphology denominated in the literature as "birds nest " (Figures 5a, $5 \mathrm{~b}$ and $5 \mathrm{c})$, which is associated with lepidocrocite $(\gamma-\mathrm{FeOOH})$, and which is common for steel in the related media [28]. This observation is confirmed by the EDS spectrum obtained for a region with this product (Figure 5d), showing high levels of $\mathrm{Fe}$ and $\mathrm{O}$. Also, it was related, for the two media, the formation of corrosion products with a dry mud aspect and presenting cracks (Figure 5f) which, according to Raman et al. [29], are constituted of mixtures of amorphous phases. The enlargement of a region of Figure $5 \mathrm{e}$, presented in Figure $5 \mathrm{~g}$, indicates the presence of goethite $(\alpha-\mathrm{FeOOH})$ in the "AP1 $+1.0 \% \mathrm{NaCl}$ " medium, which emerged from amorphous precipitates.

For the sample tested in the solution "AP2 $+1.0 \% \mathrm{NaCl}$ ", it was also verified the formation of deformed circular structures that are associated in the literature with magnetite and are called donuts [29], according to Figures $5 \mathrm{~h}$ and 5i. Figure 5i shows the formation of lepidocrocite inside a donut, and the results of EDS for the donut in Figure 5h indicated high levels of Mn and S, which suggests that the process started in a region with inclusions of $\mathrm{MnS}$, present in the microstructure of CA-50 steel in this study.

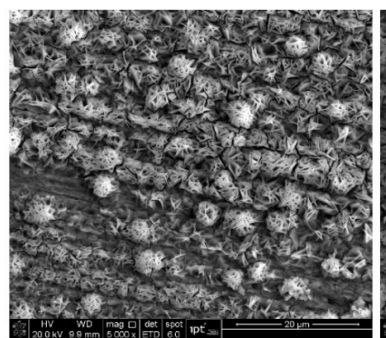

(a)

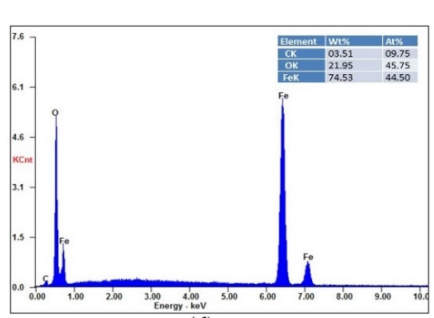

(d)

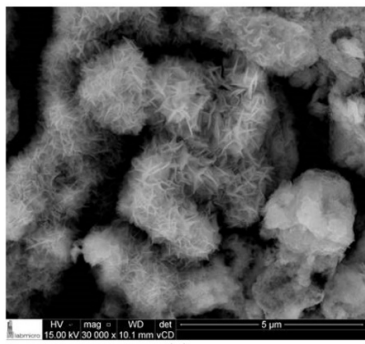

(g)

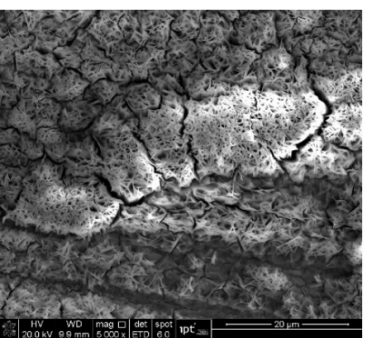

(b)

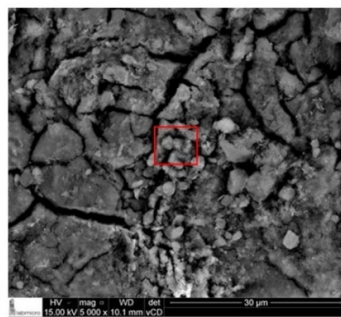

(e)

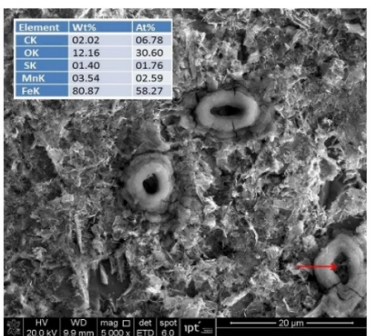

(h)

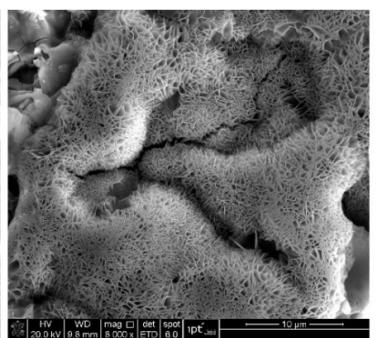

(c)

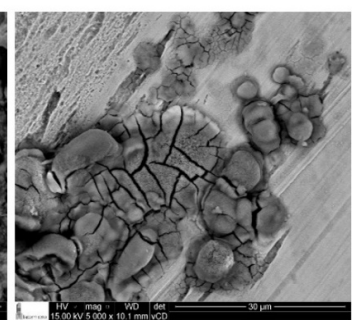

(f)

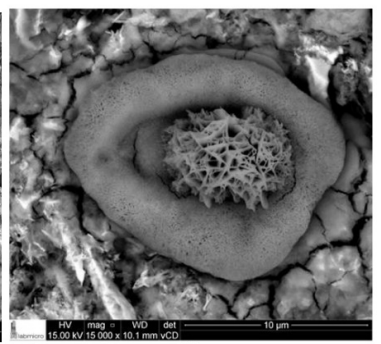

(i)

Figure 5. SEM images from the surface of CA-50 steel after anodic polarization. (a) and (b) "AP1 + 1.0\% NaCl", lepidocrocrite $(\gamma$-FeOOH) with "birds nest" morphology. Increase of 5000 X. (c) “AP2 $+1.0 \% \mathrm{NaCl}$ ”, lepidocrocyte formation $(\gamma-\mathrm{FeOOH})$.

Increase of $8000 \mathrm{X}$. (d) EDS spectrum of the region showed in figure (a). Formation of amorphous structures with dry mud morphology (cracks) in (e) "AP1 $+1.0 \% \mathrm{NaCl}$ " and (f) "AP2 $+1.0 \% \mathrm{NaCl}$ ". (g) Enlargement of the region showed in (e), with goethite formation $(\alpha-\mathrm{FeOOH})$. (h) Donut-shaped structures $\left(\mathrm{Fe}_{3} \mathrm{O}_{4}\right)$ present on the surface, with EDS result for a specific donut (indicated in the figure). (i) Donut-shaped structure with lepidocrite $(\gamma$-FeOOH). Source: Results obtained by Laboratório de Corrosão e Proteção / IPT and Laboratório de Microscopia Eletrônica de Varredura / PMT / USP. 


\section{CONCLUSIONS}

- CA-50 steel showed a passive behavior in all pore waters without the addition of $1.0 \% \mathrm{NaCl}$ in both the polarization and impedance tests during the time, which proves the efficiency of the protection given to the material by alkaline environments.

- The pore water extracted from cement pastes with steel slag (studied pore water) was more alkaline than that proposed by Oliveira [17] for cement and blast furnace slag (pore water AP1 and AP2 with compositions in Table 4) and adopted as reference. Until the end of the impedance tests (5 days), the $\mathrm{pH}$ practically did not change for the former, while for the reference media, it showed a slight drop with time.

- Tests on media with $1.0 \% \mathrm{NaCl}$ indicated advantages conferred by the studied pore waters (75CPV25EA and 75CPV25EAm) to CA-50 steel. In the polarization and EIS tests during the time, the higher alkalinity conferred greater protection to the steel, preventing its corrosion even in the presence of high chloride concentration, while in the reference media [17] the steel corroded. There was evidence of pitting potential in the anodic curves and a strong drop in impedance for longer immersion times, indicating an attack of the passive layer in the reference media. On the other hand, the EIS results for the studied pore waters (cement pastes with steel slag) indicated a downward trend in the impedance modulus with time, which can be attributed to the aggressiveness of the chloride. However, this did not promote the corrosion of the steel.

- The SEM images of the corroded region after anodic polarization in the reference pore water [17] indicated that the predominant corrosion product is lepidocrocite $(\gamma-\mathrm{FeOOH})$, characteristic of chloride attack on steel in alkaline media. Also occurred goethite $(\alpha-\mathrm{FeOOH}$, in $\mathrm{AP} 1+1.0 \% \mathrm{NaCl})$ and magnetite $(\mathrm{Fe} 3 \mathrm{O} 4)$ formations in the form of donuts $(\mathrm{AP} 2+1.0 \% \mathrm{NaCl})$. The electrodes tested in pore water of cement pastes with steel slag remained intact.

\section{ACKNOWLEDGEMENTS}

The authors thank InterCement Brazil and the Empresa Brasileira de Pesquisa e Inovação Industrial (EMBRAPII) for allowing the realization of this study in the scope of the larger project. Also, thanks to the labs of Materiais de Construção Civil (LMCC), Processos Metalúrgicos (LPM), Corrosão e Proteção (LCP) and Análises Químicas (LAQ) of IPT for the results of characterization and microstructure of materials, as well as the Laboratório de Microscopia Eletrônica de Varredura/PMT/USP for results of microstructure of steel.

\section{REFERENCES}

[1] A. Nonat, "A hidratação dos cimentos," in Durabilidade do Concreto: Bases Científicas para a Formulação de Concretos Duráveis de Acordo com o Ambiente, J. Ollivier and A. Vichot, Ed., São Paulo: IBRACON, 2014.

[2] H. Alanyali, M. Çöl, M. Yilmaz, and S. Karagöz, "Concrete produced by steelmaking slag (basic oxygen furnace) addition in Portland cement," Int. J. Appl. Ceram. Technol., vol. 6, no. 6, pp. 736-748, 2009, http://dx.doi.org/10.1111/j.17447402.2008.02317.x.

[3] M. Gautier, J. Poirier, F. Bodénan, G. Franceschini, and E. Véron, "Basic oxygen furnace (BOF) slag cooling: laboratory characteristics and prediction calculations," Int. J. Miner. Process., vol. 123, pp. 94-101, 2013, http://dx.doi.org/10.1016/j.minpro.2013.05.002.

[4] F. F. Chotoli, V. A. Quarcioni, C. Fredericci, R. E. Vieira, and J. B. Ferreira No., "Modified oxygen steelmaking slag to produce cements - Part 1: chemical and mineralogical characterization," in Proc. 14th Int. Cong. Chem. Cem., 2015.

[5] F. F. Chotoli, V. A. Quarcioni, J. B. Ferreira No., and R. F. C. Santos, "Modified oxygen steelmaking slag to produce cements - Part 2: hydration and physical-mechanical characterization," in Proc. 14th Int. Cong. Chem. Cem., 2015.

[6] A. B. Masuero, "Estabilização das escórias de aciaria elétrica com vistas a sua utilização como substituição ao cimento," Ph.D. dissertation, Esc. Eng., Univ. Fed. Rio Grande do Sul, Porto Alegre, 2001.

[7] R. D. Hooton, M. D. A. Thomas, and T. Ramlochan, "Use of pore solution analysis in design for concrete durability," Adv. Cement Res., vol. 22, no. 4, pp. 203-210, 2010., http://dx.doi.org/10.1680/adcr.2010.22.4.203.

[8] M. Moreno, W. Morris, M. G. Alvarez, and G. S. Duffó, "Corrosion of reinforcing steel in simulated concrete pore solutions - effect of carbonation and chloride content," Corros. Sci., vol. 46, no. 11, pp. 2681-2699, 2004, http://dx.doi.org/10.1016/j.corsci.2004.03.013.

[9] M. S. Moreno, "Películas passivas modificadas por el empleo de inhibidores de corrosión para la protección de armaduras. Sistemas de prevención de la corrosión," Ph.D. dissertation, Fac. Cien, Univ. Autonoma de Madrid, Madri, 2007. Accessed: Feb. 1, 2020. [Online]. Available: https://repositorio.uam.es/handle/10486/670581 
[10] M. Sánchez, J. Gregori, C. Alonso, J. J. García-Jareño, H. Takenouti, and F. Vicente, "Electrochemical impedance spectroscopy for studying passive layers on steel rebars immersed in alkaline solutions simulating concrete pores," Electrochim. Acta, vol. 52, no. 27, pp. 7634-7641, 2007, http://dx.doi.org/10.1016/j.electacta.2007.02.012.

[11] F. Zhang, J. Pan, and C. Lin, "Localized corrosion behavior of reinforcement steel in simulated concrete pore solution," Corros. Sci., vol. 51, no. 9, pp. 2130-2138, 2009, http://dx.doi.org/10.1016/j.corsci.2009.05.044.

[12] W. Chen, R. G. Du, C. Q. Ye, Y. F. Zhu, and C. J. Lin, "Study on the corrosion behavior of reinforcing steel in simulated concrete pore solutions using in situ Raman spectroscopy assisted by electrochemical techniques," Electrochim. Acta, vol. 55, no. 20, pp. 5677-5682, 2010, http://dx.doi.org/10.1016/j.electacta.2010.05.003.

[13] D. A. Koleva, N. Boshkov, K. Van Breugel, and J. H. W. Wit, "Steel corrosion resistance in model solutions containing waste materials," Electrochim. Acta, vol. 58, pp. 628-646, 2011, http://dx.doi.org/10.1016/j.electacta.2011.10.010.

[14] A. Cesen, T. Kosec, A. Legat, and V. B. Bosiljkov, "Corrosion properties of different forms of carbon steel in simulated concrete pore water," Mater. Technol., vol. 48, no. 1, pp. 51-57, 2014.

[15] R. Liu, L. Jiang, J. Xu, C. Xiong, and Z. Song, "Influence of carbonation on chloride-induced reinforcement corrosion in simulated concrete pore solutions," Constr. Build. Mater., vol. 56, pp. 16-20, 2014, http://dx.doi.org/10.1016/j.conbuildmat.2014.01.030.

[16] P. K. Mehta and P. J. M. Monteiro, Concreto: Estrutura, Propriedades e Materiais. São Paulo: PINI, 1994.

[17] C. T. A. Oliveira, “Água de poro de pastas de cimento de escória,” Ph.D. dissertation, Esc. Politéc., Univ. São Paulo, São Paulo, 2000. Accessed: Feb. 1, 2020. [Online]. Available: https://repositorio.usp.br/item/001076162

[18] R. S. Barneyback Jr. and S. Diamond, "Expression and analysis of pore fluids from hardened cement pastes and mortars," Cement Concr. Res., vol. 11, no. 2, pp. 279-285, 1981, http://dx.doi.org/10.1016/0008-8846(81)90069-7.

[19] M. P. Kulakowski, “Contribuição ao estudo da carbonatação em concretos e argamassas compostos com adição de sílica ativa,” Ph.D. dissertation, Esc. Eng., Univ. Fed. Rio Grande do Sul, Porto Alegre, 2002. Accessed: Feb. 1, 2020. [Online]. Available: https://lume.ufrgs.br/handle/10183/3594

[20] K. A. Anders, B. P. Bergsma, and C. M. Hansson, "Chloride concentration in the pore solution of Portland cement paste and Portland cement concrete," Cement Concr. Res., vol. 63, pp. 35-37, 2014, http://dx.doi.org/10.1016/j.cemconres.2014.04.008.

[21] Universidade Federal do Rio Grande do Sul. "Salinidade do ambiente marinho." UFRGS. http://mdmat.mat.ufrgs.br/acqua/Textos/concentracao.htm (accessed Feb. 1, 2020).

[22] M. Carvalho-Borges, I. B. M. Orselli, M. L. C. Ferreira, and R. Kerr, "Seawater acidification and anthropogenic carbon distribution on the continental shelf and slope of the western South Atlantic Ocean," J. Mar. Syst., vol. 187, pp. 62-81, 2018, http://dx.doi.org/10.1016/j.jmarsys.2018.06.008.

[23] R. R. Oliveira, L. P. Pezzi, R. B. Souza, M. F. Santini, L. C. Cunha, and F. S. Pacheco, "First measurements of the ocean-atmosphere $\mathrm{CO}_{2}$ fluxes at the Cabo Frio upwelling system region, Southwestern Atlantic Ocean," Cont. Shelf Res., vol. 181, pp. 135-142, 2019, http://dx.doi.org/10.1016/j.csr.2019.05.008.

[24] G. R. Meira and P. R. R. Ferreira, "Revisão sobre ensaios acelerados para indução da corrosão desencadeada por cloretos em concreto armado," Ambiente Constr., vol. 19, no. 4, pp. 223-248, 2019, http://dx.doi.org/10.1590/s1678-86212019000400353.

[25] L. Feng, H. Yang, and F. Wang, "Experimental and theoretical studies for corrosion inhibition of carbon steel by imidazoline derivative in $5 \% \mathrm{NaCl}$ saturated $\mathrm{Ca}(\mathrm{OH})_{2}$ solution," Electrochim. Acta, vol. 58, pp. 427-436, 2011, http://dx.doi.org/10.1016/j.electacta.2011.09.063.

[26] E. R. Vago and E. J. Calvo, "Electrocatalysis of oxygen reduction at $\mathrm{Fe}_{3} \mathrm{O}_{4}$ oxide electrodes in alkaline solutions," J. Electroanal. Chem., vol. 339, no. 1-2, pp. 41-67, 1992, http://dx.doi.org/10.1016/0022-0728(92)80444-9.

[27] J. J. O. Andrade, “Contribuição à previsão da vida útil das estruturas de concreto armado atacadas pela corrosão de armaduras: iniciação por cloretos,” Ph.D. dissertation, Esc. Eng., Univ. Fed. Rio Grande do Sul, Porto Alegre, 2001. Accessed: Feb. 1, 2020. [Online]. Available: https://www.lume.ufrgs.br/handle/10183/2613

[28] P. Campestrini, E. P. M. Van Westing, and J. H. W. De Wit, "Influence of surface preparation on performance of chromate conversion coatings on Alclad 2024 aluminium alloy. Part II: EIS investigation," Electrochim. Acta, vol. 46, no. 17, pp. 2631-2647, 2001, http://dx.doi.org/10.1016/S0013-4686(01)00476-5.

[29] A. Raman, S. Nasrazadani, and L. Sharma, "Morphology of rust phases formed on weathering steels in various laboratory corrosion tests," Metallography, vol. 22, no. 1, pp. 79-96, 1989, http://dx.doi.org/10.1016/0026-0800(89)90024-4.

Author contributions: R. E. Vieira: conceptualization, writing (methodology, results, review); M. M. Mennucci: conceptualization, formal analysis, review, writing; H. G. de Melo, V. A. Quarcioni: data curation, formal analysis.

Editors: Mauricio de Pina Ferreira, José Luiz Antunes de Oliveira e Sousa, Guilherme Aris Parsekian. 